\title{
EDITORIAL NOTE: AN EDITOR'S SWAN SONG-1987-1998 RECONSIDERED
}

Much "history" has been generated over the course of my editing twelve volumes of Nationalities Papers. Many significant events in the territory of primary interest of the journal have taken place with an "ethnic" or "national minority" component that will require analysis for years to come; there will, of course, be no shortage of interpretations. Fortunately, the next editor will have no difficulty finding eager contributors; an entire generation of younger scholars has grown up since Mikhail Gorbachev unwittingly set off the process that unhinged the Soviet hegemony, launching a still to be completed reshuffling of states. During this editorial watch, readers have witnessed the last years of the Soviet Union and the so-called era of post-communism. The next editor of Nationalities Papers will preside over the post post-communist period for which no appropriate term has yet been found.

The fact is, no single name can cover the multifarious developments in what once was Moscow's playground and its disparate nationalities. Almost two dozen new (and renewed) states-most of them multiethnic-occupy the space that was once the USSR and Eastern Europe. And, at this time of writing, new aspirants are struggling for a new status (e.g. Chechnya and Abkhazia) and for their sheer existence (e.g. Kosovo). No one can say for sure how many will survive in the near future (e.g. Bosnia, Georgia and Tajikistan). Ethnonationalism-ethnic conflictenergizes all of them and seriously impacts on their neighbors. Some because of their size or wealth are beginning to contemplate pursuing regional goals (Ukraine and Kazakstan); others find themselves eyed by competing aspirants (e.g. Azerbaijan is wooed by both Turkey and Iran, not to mention, from afar, the U.S.). People who were once packaged into a monolithic, mega-centrist body politic now seek to align themselves according to their own specific, self-defined individual state fears and interests. Many, if not most, seek to distance themselves from the Russian Federation as much as economics and geopolitics permit: thus, most East European states are looking west, towards membership in the European Union and NATO. Others, force majeure, must accommodate Russia in their security and market calculations (e.g. Belarus, Kazakstan and Armenia). Regionalism (Black Sea, Caspian Sea and Baltic Sea littoralisms) is another example of interstate rearrangements, motivated both by economic and by cultural (ethnic) motifs. In short, it is not the same map (politically and ethnographically) as it was a dozen years ago when I assumed the editorship of Nationalities Papers.

Massive ethno-population shifts are taking place, often prompted by vicious civil wars and aggressive, exclusionary ethnopolitics: over four million ethnic Russians have so far left former Soviet republics for Russia proper since 1991. While Armenia 
has lost all its sizeable Azeri minority, Azerbaijan no longer includes its equally large Armenian community. Hundreds of thousands of Serbs have been uprooted, as have Croats and Bozniaks, and now Kosovans; some have fled abroad as stateless refugees. Jews continue to exit from Russian and other cities, significantly altering (impoverishing) the multicultural character of urban centers like Moscow, St Petersburg and Sarajevo.

Architects of the new era have risen to power, declined and gone from the political stage: e.g. Walesa and Iliescu; Havel and Yeltsin are on their last legs. Frequent, if not always democratic, elections bring about constant reshuffles of old and new faces. What their impact will be on ethnic relations-harmonious or conflictingneeds constant assessment, for the ethnic factor as a constant irritant or potential destabilizer remains, to be identified, assessed and contextualized. The least acknowledged, though easily the most potent, is the Roma (Gypsy) factor; the Roma constitute the fastest growing minority in every European country and the problem festers closer and closer to the surface of everyday life. No government is immune. No leader can escape it.

The ethnic threat or factor has by no means diminished, whether in Estonia, in Slovakia or in Tajikistan, covertly or overtly. Nationalities Papers' raison d'être has by no means diminished as a result from the shift to the "New" Europe; its mandate, dating back to 1972 when the journal was founded, is intact and need not be fundamentally altered despite the tumult of the past twelve years. May the next twelve years be as challenging. A steady course is the only word of unsolicited advice to those who follow.

To end, briefly, on a personal note. If the previous twelve volumes of Nationalities Papers have been a success then it is only right to indulge in some final expression of gratitude to those who made editing this journal a challenging intellectual adventure. Credit must first go to the members of the Editorial Board for steadfast loyalty and prudent advice. Considerable credit goes to the Division of Humanities of the City College of New York for unstinting support well beyond the usual number of years. Thanks to two successive deans, Paul Sherwin and Martin Tamny, whose respect for scholarship was unwavering, Nationalities Papers had the security of an institutional home and the editor the indispensable help over the years of superb editorial assistants: Dallas Arnold, Marianne Guenot, Sondra Kitchen and Sandrine Dikambi. Not to be forgotten are the congenial and very professional colleagues - especially David Green - at Carfax Publishing, the journal's publisher in England. Finally, my best wishes to my able successor, Nancy Wingfield; my thanks to her for taking over the duties of editor-in-chief. 